\title{
UNEXPLAINED RELATIONSHIPS OF HEIGHT-DIAMETER OF THREE TREE SPECIES IN A TROPICAL FOREST
}

\author{
T.0. DAUDA ${ }^{1, *}$ \\ L.O. OJO2 \\ S.K. NOKOE 1
}

\author{
${ }^{1}$ Department of Mathematical Science \\ University of Agriculture, Abeokuta, Nigeria \\ ${ }^{2}$ Department of Environmental Management and Toxicology \\ University of Agriculture, Abeokuta, Nigeria
}

*to whom all correspondence should be addressed:

\section{ABSTRACT}

Associations between bivariate variables relative to the unexplained relationships of height-Dbh (diameter at breast height) models were investigated. Seven permanent sample plots measuring $40 \mathrm{~m}$ by $250 \mathrm{~m}$ at Omo Forest Reserve were used to assess the relationships between height and diameter at breast height of three tree species as affected by the variables of neighbouring trees. The result showed differences in the coefficient of determination of the bivariate models and multivariate models. The models arrived at for each of the species and for the bivariate models are:

Scottelia coriaceae: $H t=2.59+0.473 D+0.0012 D^{2}$ for $5 \mathrm{~cm} \leq \mathrm{D} \leq 100 \mathrm{~cm}\left(\mathrm{R}^{2}=0.70\right)$

Sterculia rhinopetala: $H t=5.96+0.467 D+0.00296 D^{2}$ for $5 \mathrm{~cm} \leq \mathrm{D} \leq 100 \mathrm{~cm}\left(\mathrm{R}^{2}=0.77\right)$

Strombosia pustulata: $H t=2.02+0.722 D+0.00581 D^{2}$ for $5 \mathrm{~cm} \leq \mathrm{D} \leq 60 \mathrm{~cm}\left(\mathrm{R}^{2}=0.81\right)$

Where both Ht and D are height and Diameter at breast height.

While on the other hand the multivariate models that considered the effect of neighbouring trees are:

Scottelia coriaceae: $H t=3.74+0.41 x_{1}-1.14 x_{2}+0.205 x_{3}+1.278 x_{4}\left(\mathrm{R}^{2}=0.723\right)$

Sterculia rhnopetala: $H t=6.18+0.2601 x_{1}+1.163 x_{2}+0.438 x_{3}-0.442 x_{4}\left(\mathrm{R}^{2}=0.608\right)$

Strombosia pustalata: $H t=6.84+0.399 x_{1}-0.318 x_{2}-0.138 x_{3}-0.838 x_{4}\left(\mathrm{R}^{2}=0.650\right)$

$\mathrm{x}_{1}=$ diameter at breast height, $\mathrm{x}_{2}=$ Mean neighbouring tree distance, $\mathrm{x}_{3}=$ Frequency of the neighbouring tree and $\mathrm{x}_{4}=$ Position of the crown.

KEYWORDS: Unexplained relationship, Neighbouring tree, Diameter at breast height (Dbh).

\section{INTRODUCTION}

Associations in bivariate modeling are usually investigated in forestry to boost the reliability of prediction to save cost, minimize task and time spent in data collection. These data are of prime importance for varying forest management techniques. According to Okojie (1985) and Vanclay (1989 and 1995), these models are useful 
in investigating different rules for logging selection, silvicultural treatment and others. Regression analysis is one of the tools usually employed to investigate the nature of the association between two or more variables via models (equations). The degree or extent of the association is determined using coefficient of determination $\mathrm{R}^{2}$. The coefficient of determination $\mathrm{R}^{2}$ is useful in determining the total variability accounted for by the regression equation. The closer the value is to one " 1 " the stronger the relationships and vice versa between the variables. That is " 1 " implies perfect relationships between bivariate models (which is a rare case, Zar, 1984). Coefficient of determination $\mathrm{R}^{2}$ therefore arrived at, explained relationships leaving behind some relationships unexplained. These unexplained relationships are those from variables not considered in the modeling. In height- Dbh modeling of tree species in a tropical forest for instance, other factors like those relating to neighbouring trees are examples of unexplained relationships.

Similarly, two approaches to modeling have been stressed by Bruenig et al., (1986) and are statistical and structural approaches. Statistical approaches established a relationship between observed output and known input of a system by their variables. Structural modeling approach, in addition, uses available structural knowledge about the system. However, the statistical modeling approach is described as often arbitrary and structurally invalid because it cannot reflect the possible structural changes in the system, (Bruenig et al., 1986). Modeling unexplained relationship of height diameter relationship can therefore meet these challenges of reducing errors in the prediction of height from diameter at breast height. Also, the pattern of growth of tree species according to Philip (1998) is affected by a number of factors among which is competition. It is therefore expedient to incorporate competition factors when modeling height-diameter relationship of tree species in a forest, which is the focus of this study. The objective of this study is thus to investigate the effects of neighbouring tree species parameter on the height-diameter models of some tree species in a natural forest. This will be done by modeling the relationships between height-diameter of some tree species based on the effects of neighbouring tree parameters and find the intra-relationships of these variables within themselves.

\section{MATERIALS AND METHOD \\ The Study Area}

The study area (Figure 1) is located within Abeku sector of Omo Forest Reserves. It falls between $6^{0} 35^{!}$to $7^{0} 05^{!} \mathrm{N}$ and $4^{0} 19^{!}$to $4^{0} 40^{!}$in the southwest of Nigeria (Okali and Ola Adams, 1987; Ola Adams et al., 1998). Omo Forest Reserves, which covers $1167 \mathrm{~km}^{2}$, was established in 1916 but gazetted by order No 10 of 1925, (Weeks, 1996). The forest reserve, formerly part of Shasha forest reserve now shares boundaries with Shasha forest reserve, Oluwa forest reserve and Ondo state afforestation project. Topographically, the area is undulating and dominated by slopes which reaches between $15 \mathrm{~m}$ and $150 \mathrm{~m}$ above sea level, (Okali and Ola Adams, 1987). The area falls within the tropical wet and dry climate and is characterized by two (2) rainfall peaks with a less humid period usually in the month of August separating the two peaks, (Ola Adams et al.,1998). Mean Annual rainfall is about $1750 \mathrm{~mm}$ and mean relative humidity is $80 \%$, (Ola Adams, 1999). Again, the mean daily temperature is $26.4{ }^{\circ} \mathrm{C}$ and relative humidity is generally around $95 \%$ at dawn, usually the time of minimum temperature.

\section{Vegetation of the Study Area}

The vegetation of the study area is mixed/moist semi evergreen rainforest. However, a dry green mixed deciduous forest in the northern part and a wet evergreen forest in the greater southern parts of the reserve were identified by Okali and Ola Adams (1987). More than 750 individual stems of 95 species were encountered during the sampling. These were mostly, Strombosia pustulata, Terbanaemontana pachysiphon, Anthostema aubreyanum, and Diospyros iturensis.

\section{Data collection}

Data were collected from seven permanent sample plots of one hectare each established at the Abeku sector of Omo Forest Reserve by High Forest monitoring plots project (HFMPP) of the Federal Department of Forestry. Each plot of one hectare was offset perpendicularly $50 \mathrm{~m}$ from the reference baseline. The centreline of those plots was demarcated and marked into quadrats of $50 \mathrm{~m}$. Each quadrat is further subdivided in to 10 
segments of $5 \mathrm{~m}$ each. Tree height data comprising both merchantable and total height were collected at three levels.

- Small trees 50-200mm dbh within 2.5m either side of centerline.

- Medium trees 200-400mm dbh within 5m either side of centerline.
Trees were recorded relative to their position on the quadrat in which they weer found. This would enable locating the trees easily in subsequent remeasurement. Trees, which were $50 \mathrm{~mm} \mathrm{dbh}$ and above were enumerated appropriately for both total height and diameter at breast height.

- Large trees $>400 \mathrm{~mm}$ dbh in the entire plot.

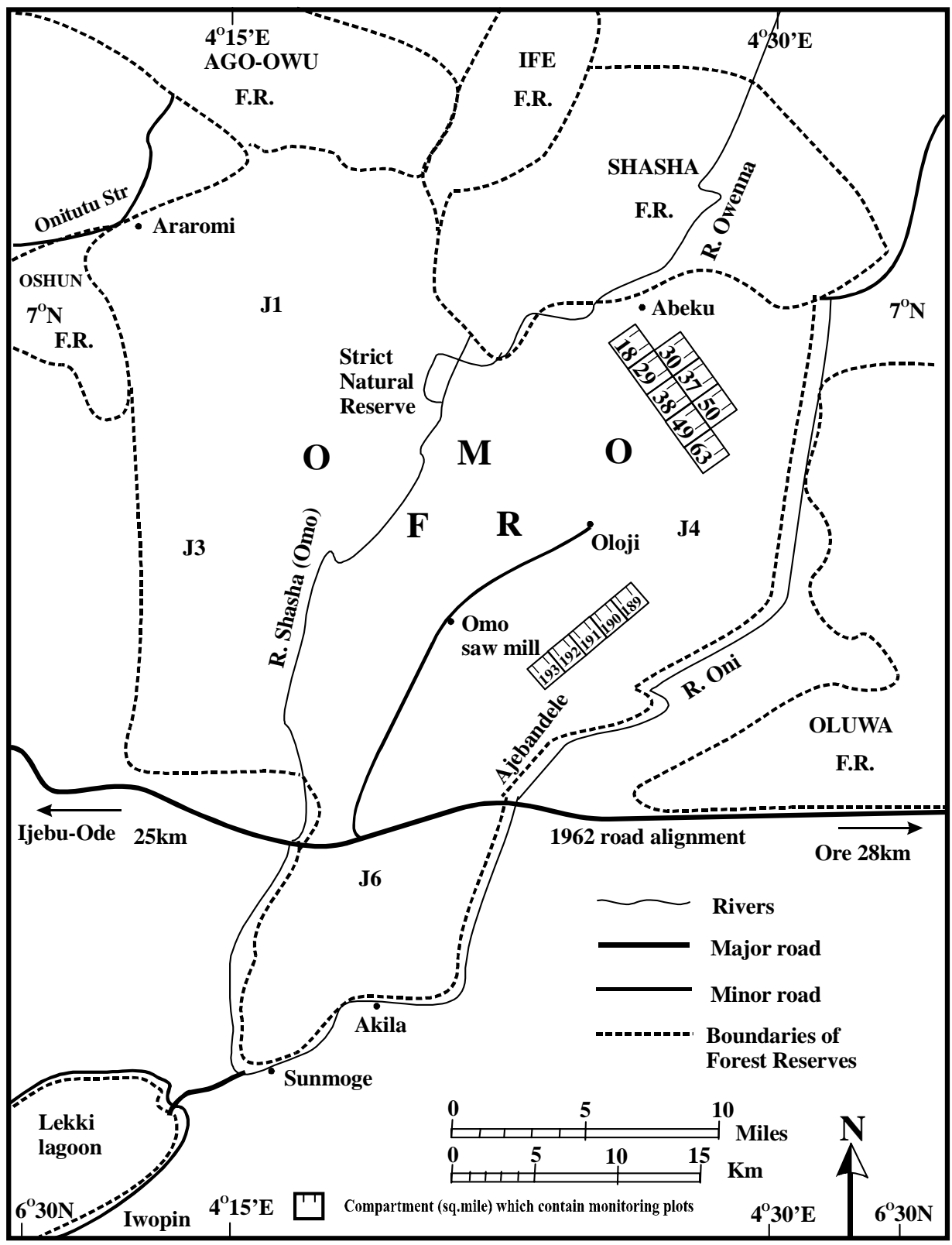

Figure 1. Map of Omo Forest Reserve showing the position of Abeku, the study site 


\section{Data analysis}

All the tree species found in the study area were first screened to the ten species used for the bivariate models based on their frequency and economic importance concerning wood production. These were Strombosia pustulata, Terbanaemontana pachysiphon, Anthostema aubreyanum, and Diospyros iturensis, Octolobus spectabilis, Sterculia rhinopetala, Diopyros dendo, Diospyros suaveolense, Hunteria umbellate and Scottelia coriacea. These ten species were further screened to the three species for the multivariate models. For the bivariate model (that is heightdiameter model) both linear, non-linear and logarithm transformed model were employed to investigate the relationships.

The model that performs best for each of the species was chosen using F-test and based on the magnitude of coefficient of determination, $\mathrm{R}^{2}$. This was used to screen the ten species to the three species used for the multivariate modeling. For the Multiple linear regression analysis, additional variables to the height and diameter at breast height were;

1. Neighbouring tree distance: This represents the mean distance of the trees within $2.5 \mathrm{~m}$ radius to any of the three selected tree species, (Vanclay, 1995).

2. Crown position of neighbouring tree: This considers the crown position of the neighbouring tree relative to any of the selected tree species. If it is above reference tree, it is allotted a coefficient of one but if it is below it is zero.

3. Frequency of the neighbouring tree: This is the number of trees within $2.5 \mathrm{~m}$ radius to the reference tree, regardless of the species.

The datasets collected from the experiment designed in a complete randomized design were subjected to the various analysis using MINITAB and STATISTICA

\section{RESULTS}

The frequencies of the selected trees are 15, 22 and 50 for Scottelia coriaceae, Sterculia rhinopetala and Strombosia pustulata respectively (Table 1). Table 2 shows some descriptive statistics (that is the minimum and maximum values) of the variables for each of the three species used in the models. Highest values of all the variables (DBH, Height, Mean distance, frequency and crown nature of neighbouring trees) were recorded in Sterculia rhinopetala, while the lowest diameter at breast height (dbh) was also recorded in Sterculia rhinopetala, (Table 2). Correlation coefficient, which establish the relationship between the variables and Dbh and among all the other variables for each specie are presented in table 4-6. For Scottelia coriaceae, highest relationships was observed between Dbh and height and which was significant at $1 \%$ significance level. This was followed by the relationship between Dbh and Mean neighbouring trees' distance, which is only significant at 5\% significance level. The lowest and inverse relationships exist between Dbh and crown position. This relationship (that is Dbh and crown position) was not significant at 5\% significance level, judging by the coefficient of determination, $\mathrm{R}^{2}$, (Table 3 and 6 ).

Similarly, for Sterculia rhinopetala, highest relationships exist between Dbh and height, which was significant at $1 \%$ significance level using the coefficient of determination, $\mathrm{R}^{2}$. Also, the relationship between the crown position and frequency of the neighbouring tree was significant at $1 \%$ significance level. Lowest and inverse relationship exists between crown position and Dbh and it was not significant at 5\% significance level, (Table 4 and 6).

The relationships between height and Dbh of Strombosia pustulata was the highest and it was significant at $1 \%$ significance level. This was followed by that (the relationship) existing between the frequency and crown position of the neighbouring trees to the specie (Strombosia pustulata) The weakest relationship according to the value of coefficient of determination $\mathrm{R}^{2}$ exist between mean distances of neighbouring trees. This is also significant at $1 \%$ significance level. Least and inverse relationship exist between the crown position of the neghbouring tree and the height of Strombosia pustulata. These relationships as well as the other not stress are not significant at 5\% significance level when judged by the coefficient of determination, $\mathrm{R}^{2}$ (Table 5 and 6).

Two bivariate models chosen for these species are of the form:

$$
\begin{aligned}
& \mathrm{Ht}=\mathrm{a}+\mathrm{b}_{1} x+b_{2} x^{2} \\
& H t=a+b+\log _{e} D
\end{aligned}
$$


$\mathrm{b}_{2}=$ regression coefficient and $\mathrm{x}=\mathrm{Dbh}$.

These bivariate models are:

Scottelia coriaceae: $H t=2.59+0.473 D+0.0012 D^{2}$ for $5 \mathrm{~cm} \leq \mathrm{D} \leq 100 \mathrm{~cm}\left(\mathrm{R}^{2}=0.70\right)$

Sterculia rhinopetala: $H t=5.96+0.467 D+0.00296 D^{2}$ for $5 \mathrm{~cm} \leq \mathrm{D} \leq 100 \mathrm{~cm}\left(\mathrm{R}^{2}=0.77\right)$

Strombosia pustulata: $H t=2.02+0.722 D+0.00581 D^{2}$ for $5 \mathrm{~cm} \leq \mathrm{D} \leq 60 \mathrm{~cm}\left(\mathrm{R}^{2}=0.81\right)$

Table 1. The selected species used for the study and their utility according to Ward (1974)

\begin{tabular}{|l|l|l|l|}
\hline $\begin{array}{l}\text { Spp } \\
\text { no }\end{array}$ & Species names & $\begin{array}{l}\text { Total } \\
\text { Freq. }\end{array}$ & Utility. \\
\hline 1 & Strombosia pustulata & 50 & For heavy construction, (Group 2 Utility class) \\
\hline 2 & Sterculia rhinopetala & 22 & Veneers and Furniture timber Species. \\
\hline 3 & Scottelia coriacea. & 15 & For heavy construction, (Group 2 Utility class) \\
\hline & Total & 87 & \\
\hline
\end{tabular}

Table 2. Minimum and maximum values of the variables used in the models.

\begin{tabular}{|c|c|c|c|c|c|c|c|c|c|c|}
\hline \multirow[t]{2}{*}{ Spp } & \multicolumn{2}{|l|}{$\begin{array}{l}\text { DBH } \\
\text { (cm) }\end{array}$} & \multicolumn{2}{|c|}{$\begin{array}{l}\text { HEIGHT } \\
(\mathrm{m})\end{array}$} & \multicolumn{2}{|c|}{$\begin{array}{l}\text { MEAN NT. } \\
\text { (m) }\end{array}$} & \multicolumn{2}{|c|}{$\begin{array}{l}\text { FREQ.OF } \\
\text { NT. }\end{array}$} & \multicolumn{2}{|c|}{$\begin{array}{l}\text { CROWN } \\
\text { POSITION }\end{array}$} \\
\hline & Min & Max & Min & Max & Min & Max & Min. & Max & Min & Max \\
\hline Scottelia coriaceae & 8.0 & 52.8 & 3.5 & 25.0 & 0.3 & 1.7 & 0 & 6 & 0 & 3 \\
\hline Sterculia rhinopetala & 6.8 & 58.3 & 7.5 & 26.0 & $0 . .4$ & 3.2 & 1 & 9 & 0 & 4 \\
\hline Strombosia pustulata & 7.0 & 43.3 & 4.0 & 25.0 & 0.2 & 2.2 & 0 & 6 & 0 & 3 \\
\hline
\end{tabular}

$\mathrm{DBH}=$ Diameter at breast height

NT. $=$ Neighbouring Tree

FREQ.= Frequency

Table 3. Correlation matrix between the variables for neighbouring tree analysis for Scottelia coriaceae in Omo Forest Reserve, Nigeria

\begin{tabular}{|l|c|c|c|l|l|}
\hline & DBH & Mean NTD & $\begin{array}{l}\text { Freq of } \\
\text { neighbouringtree. }\end{array}$ & $\begin{array}{l}\text { Crown } \\
\text { position }\end{array}$ & Height \\
\hline DBH & 1.000 & & & & \\
\hline Mean NTD & $0.531^{*}$ & 1.000 & & & \\
\hline $\begin{array}{l}\text { Freq of } \\
\text { neighbouring tree. }\end{array}$ & 0.350 & 0.444 & 1.000 & & \\
\hline Crown position & -0.277 & 0.350 & 0.405 & 1.000 & \\
\hline Height & $0.829^{* *}$ & 0.432 & 0.407 & -0.049 & 1.000 \\
\hline
\end{tabular}

$\mathrm{R}_{15(0.05)}=0.521, \mathrm{R}_{15(0.01)}=0.654$

Crown P.= Crown Position, welther above or below the reference tree

$\mathrm{DBH}=$ Diameter at breast height

NT. $=$ Neighbouring Tree

FREQ.= Frequency 
Table 4. Correlation Matrix between the Variables for Neighboring tree Analysis for Sterculia rhinopetala in Omo Forest Reserve, Nigeria

\begin{tabular}{|l|c|c|c|c|c|}
\hline & DBH & Mean NTD & $\begin{array}{l}\text { Freq of } \\
\text { neighbori } \\
\text { ng tree. }\end{array}$ & $\begin{array}{l}\text { Crown } \\
\text { positio } \\
\text { n }\end{array}$ & Height \\
\hline DBH & 1.000 & & & & \\
\hline Mean NTD & -0.277 & 1.000 & & & \\
\hline $\begin{array}{l}\text { Freq of } \\
\text { neighbouring tree. }\end{array}$ & -0.048 & -0.420 & 1.000 & & \\
\hline Crown position & -0.354 & -0.067 & $0.651^{* *}$ & 1.000 & \\
\hline Height & $0.770^{* *}$ & -0.129 & -0.017 & -0.281 & 1.000 \\
\hline
\end{tabular}

$\mathrm{R}_{22(0.05)}=0.452, \mathrm{R}_{22(0.01)}=0.544$.

Crown P.= Crown Position, whelther above or below the reference tree.

$\mathrm{DBH}=$ Diameter at breast height.

NT. $=$ Neighbouring Tree.

FREQ.= Frequency.

Table 5. Correlation Matrix between the Variables for Neighboring tree Analysis for Strombosia pustulata in Omo Forest Reserve, Nigeria

\begin{tabular}{|l|c|c|c|c|c|}
\hline & DBH & Mean NTD & $\begin{array}{l}\text { Freq of } \\
\text { neighbouring } \\
\text { tree. }\end{array}$ & $\begin{array}{l}\text { Crown } \\
\text { position }\end{array}$ & Height \\
\hline DBH & 1.000 & & & & \\
\hline Mean NTD & 0.131 & 1.000 & & & \\
\hline $\begin{array}{l}\text { Freq of } \\
\text { neighbouring } \\
\text { tree. }\end{array}$ & 0.073 & $0.485^{* *}$ & 1.000 & & \\
\hline $\begin{array}{l}\text { Crown } \\
\text { position }\end{array}$ & -0.291 & 0.274 & $0.660^{* *}$ & 1.000 & \\
\hline \begin{tabular}{l} 
Height \\
\hline
\end{tabular} & $0.782^{* *}$ & -0.005 & -0.107 & -0.407 & 1.000 \\
\hline
\end{tabular}

$\mathrm{R}_{50(0.05)}=0.279, \mathrm{R}_{50(0.01)}=0.363$

Crown p. $=$ Crown Position, welther above or below the reference tree

$\mathrm{DBH}=$ Diameter at breast height

NT. $=$ Neighbouring Tree

FREQ.= Frequency 


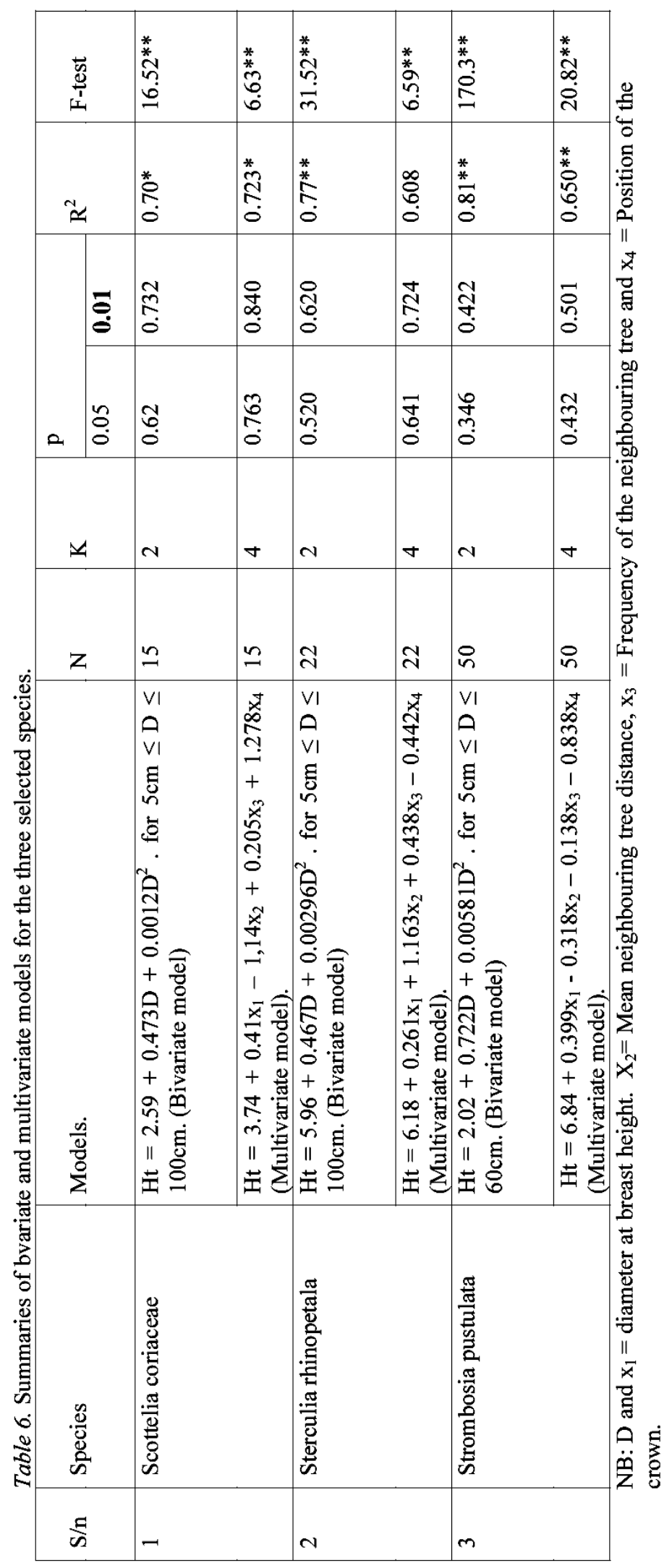


These models, (except that for the Scottelia coriaceae) which are of the second order polynomials are all significant at $1 \%$ significance level using both coefficient of determination $\mathrm{R}^{2}$ and the F-statistics. The model for the Scottelia coriaceae is significant only at $5 \%$ probability level. However, the multivariate models, which were computed through the structural modeling approach, are of the form:

$$
H t=a+b_{1} x_{1}-b_{2} x_{2}+b_{3} x_{3}+b_{4} x_{4}
$$

Where $a=$ the intercept, $b_{1}$ to $b_{4}=$ regression coefficient and $\mathrm{x}_{1}, \mathrm{x}_{2}, \mathrm{x}_{3}, \mathrm{x}_{4}$ are respectively the various variables including the diameter at breast height. These models are:

Scottelia coriaceae: $\quad H t=3.74+0.41 x_{1}-1,14 x_{2}+0.205 x_{3}+1.278 x_{4}\left(R^{2}=0.723\right)$

Sterculia rhnopetala: $\quad H t=6.18+0.261 x_{1}+1.163 x_{2}+0.438 x_{3}-0.442 x_{4}\left(R^{2}=0.608\right)$

Strombosia pustalata: $\quad H t=6.84+0.399 x_{1}-0.318 x_{2}-0.138 x_{3}-0.838 x_{4}\left(R^{2}=0.650\right)$

The models are all significant at $1 \%$ significance level using the F-test. The F values of 6.63, 6.59 and 20.82 were computed respectively for Scottelia coriaceae, Sterculia rhinopetala and Strombosia pustulata. However, when the multiple coefficient of determination $\mathrm{R}^{2}$ is used the multi variate linear models for Strombosia pustalata only is significant at $1 \%$ level while those for Scottelia coriaceae and Sterculia rhnopetala are not significant. The multi variate model for Scottelia coriaceae was not significant at 5\% significance level. The absolute differences existing between the coefficient of determination $\mathrm{R}^{2}$ for the bivariate and multivariate models are 0.015, 0.10 and 0.094 for Scottelia coriaceae, Sterculia rhinopetala and Strombosia pustulata respectively (Table 6). Although, these are due to differences in the number of variables involved (that is $\mathrm{K}$ ) but the differences are of both positive and negative value.

\section{DISCUSSION AND CONCLUSION}

Highest relationships existed between Dbh and height of the three selected species. This corroborates the validity of the height-Dbh models used to screen the ten species for the multivariable models. The relationship between the crown position and the mean distance of neighbouring tree is said to be positive for Strombosia pustulata. This may be due to the fact that the specie is to some degree exhibit some level of allelopathy (Vanclay, 1989). Thus, the farther the distance away from the tree, the more neghbouring trees that can be found. The same reason in addition to the effect of shade on understory can be adduced for the relationship between crown position and frequency of the neighboring tree of the
Strombosia pustulata. For the other species ( Scottelia coriaceae, and Sterculia rhinopetala), the reason can simply be hinged on the effects of shade on understory (Phillips,1998).

The bivariate model (equation iii to $v$ ) can predict height when information on diameter at breast height is available and within the stipulated range. However, when information on the neighbouring tree is available in addition to the diameter at breast height, the following multivariate models (equation vii to $i x$ ) can be used. The nonsignificance of the multivariate models for some of the species does not imply that the neighbouring tree parameters are not important. The significance or otherwise of the models can be linked with the number of the significant relationship of the variables and also the level of such significance. For instance, Strombosia pustulata whose multivariate models is significant at $1 \%$ significance level has three (3) of the four variables for the multivariate models are significant at $1 \%$ significance level (table 3-5). Similaly, it can be hinged on the frequency of the observation.

The absolute differences existing between the coefficients of determination, $\mathrm{R}^{2}$ of bivariate and multivariate model can imply the unexplained relationships. This is because the difference is of both negative and positive value.

It is recommended that non-linear multi-variate model should be employed to investigate the effects of neighbouring trees' variable of the model. Also, the scope of this study can be expanded to cover most other vegetation types within and outside the country. 


\section{REFERENCES}

Bruenig E.F., Bossel H., Elpel P., Grossmann W-D., Schneider T.W., WangZhu-hao and Yuzuoyue (1986), Ecologic-Socioeconomic System Analysis and Simulation: A Guide for Application of system Analysis to the Conservation, Utilization and Development of Tropical and subtropical Land Resources in China, CRCUDS, 388.

Okali D.U. and Ola Adams B.A. (1987), Tree Population Changes in treated Rainforest at Omo Forest Reserve, South Western Nigeria, Journal of Tropical Ecology, 3, 291-312.

Okojie J.A. (1985), Height-Diameter Model for Taungya Plantation of Nauclea dideriichi, Journal of Tropical Forest Resources, 75-83.

Ola Adams B.A., Ojo L.O. and Adetunji M.T. (1998), Accumulation of Soil Nutrients under different Forest Land uses, Nigeria Journal of Forestry, 28, 5-14.

Ola Adams B.A. (1999), Biodiversity Inventory Of Omo Biosphere Reserve, Nigeria - Country Report on Biosphere Reserves for Biodiversity Conservation and Sustainable Development, Abeokuta, Gbemi Sodipo Press, pp 351.

Philip S.M. (1998), Measuring Trees and Forest, New York: University Press, $2^{\text {nd }}$ edition, pp309.

Vanclay J.K. (1989), A growth Model North Queensland Rainforest, Forest Ecology and Management, 27, 245-271.

Vanclay J. K. (1995), Growth Models for Tropical Forest: A synthesis of Models and Methods, Forest Science, 41, 7-33.

Ward D.W. (1974), Grouping of Nigerian Wood According to General Properties and End use performance, Federal Department of forestry, pp36.

Weeks (1996), Omo Forest Reserve Enumeration Survey" In: Biosphere Reserves for Biodiversity Conservation and Sustainable Development in Anglophone Africa: Assessment and Monitoring, Ola Adams B.A and Ojo L.O. (eds), pp 45-49.

Zar J.H. (1984), Biostatistical Analysis, New Jersey: Prentice- Hall Inc., $2^{\text {nd }}$ editon, pp 718. 